\title{
PENYULUHAN DALAM RANGKA PENINGKATAN PENGETAHUAN MURID SEKOLAH MENENGAH ATAS TERHADAP KEAMANAN PJAS (PANGAN JAJANAN ANAK SEKOLAH) DI SMAS AL MUSLIMUM SEI. KIJANG PELALAWAN
}

\author{
Denia Pratiwi, Ira Oktaviani RZ, Isna Wardaniati, Wahyu Margi S \\ Universitas Abdurrab, Jl. Riau Ujung No 73 \\ Prodi DIII Anafarma, Fakultas Kedokteran dan Ilmu Kesehatan \\ Email: denia.pratiwi@univrab.ac.id
}

\begin{abstract}
ABSTRAK
Keamanan pangan merupakan hal yang sangat penting dan harus melekat pada pangan yang masyarakat konsumsi, salah satunya adalah keamanan PJAS (Pangan Jajanan Anak Sekolah). Anak sekolah rentan memiliki perilaku jajan yang tidak sehat karena rendahnya pengetahuan dan kesadaran mereka dalam perilaku hidup bersih dan sehat. Padahal banyak data yang menunjukkan tidak sehatnya jajanan pangan pada anak sekolah yang dijual bukan di kantin sekolah. Tujuan dari pengabdian ini untuk mengusahakan peningkatan derajat kesehatan masyarakat melalui upaya promotif, preventif dan kuratif secara komprehensif dan untuk meningkatkan pengetahuan murid sekolah SMA tentang keamanan PJAS (Pangan Jajanan Anak Sekolah). Pengabdian ini menggunakan randomized pre-test post test control group design menggunakan alat ukur berupa kuisioner yang diberikan sebelum dan sesudah penyuluhan dengan 2x perlakuan. Hasil yang didapat terdapat peningkatan pengetahuan dan sikap anak SMA terhadap keamanan PJAS. Hal ini tentu sangat penting untuk meningkatkan kesadaran anak sekolah tentang pentingnya untuk dapat bersikap waspada terhadap jajanan pangan yang berbahaya.
\end{abstract}

Kata Kunci : keamanan PJAS, anak sekolah, perilaku hidup sehat

\section{ABSTRACT}

Food safety is very important and must be attached to the food that the consumption community, one of which is the security of PJAS (School Children Food Snacks). School children are susceptible to having unhealthy snack behavior because of their low knowledge and awareness in hygienic and healthy living behavior. Even though there are a lot of data showing unhealthy food snacks for school children sold not in the school canteen. The purpose of this service is to strive to improve the level of public health through comprehensive promotive, preventive and curative efforts and to increase the knowledge of high school students about the security of PJAS (School Children Food Snacks). This service uses a randomized pre-test post test control group design using a measuring instrument in the form of questionnaires given before and after counseling with $2 x$ treatment. The results obtained were an increase in knowledge and attitudes of high school children towards PJAS security. This is certainly very important to increase the awareness of school children about the importance of being alert to dangerous food snacks.

Keywords : PJAS Security, school children, healthy behavior 


\section{PENDAHULUAN}

Keamanan pangan merupakan hal yang sangat penting dan harus melekat pada pangan yang masyarakat konsumsi, salah satunya adalah keamanan PJAS (Pangan Jajanan Anak Sekolah). Situasi PJAS di Indonesia berdasarkan info Pusdatin Kemenkes RI tahun 2014 dari tahun 2010-2013 persentase PJAS yang memenuhi syarat (MS) mengalami peningkatan dari $55,52 \%$ menjadi $80,79 \%$ sedangkan pada tahun 2014 terjadi penurunan PJAS yang memenuhi syarat sebesar $76,18 \%$ padahal targetnya adalah $90 \%$. Target yang tidak tercapai menandakan bahwa keamanan pangan masih menjadi masalah penting. Data pengawasan PJAS yang dilakukan oleh BPOM (Balai Besar Pengawasan Obat dan Makanan) RI cq Direktorat Inspeksi dan Sertifikasi Pangan bersama 26 Balai Besar di seluruh Indonesia pada tahun 2007 menunjukkan bahwa 45\% PJAS tidak memenuhi syarat karena mengandung bahan kimia berbahaya seperti formalin, boraks, rhodamin, BTP (Bahan Tambahan Pangan) seperti siklamat dan benzoate melebihi batas aman serta mengandung S. aureus dan E. Coli melebihi batas.

Kualitas SDM yang menjadi penggerak pembangunan di masa yang akan datang ditentukan oleh bagaimana pengembangan SDM saat ini termasuk saat sekolah. Pembentukan kualitas SDM sejak masa sekolah akan mempengaruhi kualitasnya pada saat mereka mencapai usia produktif (Andarwulan, Kusnandar and Herawati, 2014). Anak sekolah rentan memiliki perilaku jajan yang tidak sehat karena rendahnya pengetahuan dan kesadaran mereka dalam perilaku hidup bersih dan sehat. Padahal banyak data yang menunjukkan tidak sehatnya jajanan pangan pada anak sekolah yang dijual bukan di kantin sekolah. Pada data KLB (Kejadian Luar Biasa) keracunan pangan menunjukkan bahwa 19\% kejadian keracunan terjadi di lingkungan sekolah. Hasil penelitian Badan POM pada 2006-2010 menunjukkan 40-44\% jajanan anak di sekolah tidak memenuhi syarat keamanan pangan. Perlu dilakukannya suatu penyuluhan untuk memberikan pengetahuan kepada anak sekolah akan pentingnya memiliki perilaku jajan yang sehat. Hal ini berdasarkan penelitian dimana siswa yang diberikan pendidikan kesehatan dapat memperbaiki perilaku siswa dalam jajan sembarangan (Aini, 2017). Perubahan perilaku meliputi perubahan pada pengetahuan, sikap dan praktik. Penyuluhan akan dilaksanakan di sekolah SMAS Al Muslimun Sei Kijang Pelalawan dimana sekolah ini banyak terdapat penjaja makanan di luar sekolah selain kantin yang ada dalam lingkungan sekolah. Murid sekolah bebas untuk berbelanja pada saat waktu istirahat sekolah. Perlu adanya pengetahuan dan kesadaran tiap siswa untuk dapat memilih jajanan yang sehat dan aman.

Keamanan PJAS merupakan hal yang sangat penting karena tidak bisa dipungkiri bahwa jajanan juga memberikan kontribusi energi terhadap anak sekolah karena anak sekolah biasanya membeli pangan jajanan pada penjaja pangan sekolah atau di kantin sekolah. Mereka biasanya tidak memikirkan apakah jajanan yang mereka beli sehat dan bersih yang penting hanya jajanan itu enak dan murah. Padahal sudah banyak ditemukan kasus keracunan makanan di sekolah disebabkan makanan yang tidak sehat dan bersih dan foodborne disease (penyakit bawaan makanan) yang bisa bersifat toksik maupun infeksius disebabkan oleh agen-agen penyakit yang masuk ke dalam tubuh melalui konsumsi makanan yang terkontaminasi. Sehingga perlu adanya pemberian informasi berupa penyuluhan kepada anak sekolah sebagai bentuk peningkatan pengetahuan mereka supaya dapat merubah sikap dan perilaku menjadi perilaku jajanan sehat. 


\section{TINJAUAN PUSTAKA}

Keamanan pangan adalah kondisi dan upaya untuk mencegah pangan dari kemungkinan cemaran biologis, kimia dan benda lain yang mengganggu, merugikan dan membahayakan kesehatan manusia. Program pengawasan pangan adalah program penunjang dalam bidang pangan yang ditujukan untuk melindungi masyarakat sehingga tidak mengkonsumsi pangan yang tidak memenuhi syarat kesehatan, mutu, gizi, dan bertentangan dengan keyakinan masyarakat. Pangan harus berdasarkan suatu standar sehingga tidak merugikan dan membahayakan kesehatan konsumen .

Pangan yang tidak aman dapat menyebabkan penyakit yang disebut dengan foodborne disease yaitu gejala penyakit yang timbul akibat mengkonsumsi pangan yang mengandung bahan/senyawa beracun atau organisme patogen (Thah and Yuwono, 2014).

Pengetahuan adalah hasil penginderaan manusia, atau hasil tahu seseorang terhadap objek melalui indra yang dimilikinya (mata, hidung, telinga dan sebagainya. Dengan sendirinya pada waktu penginderaan sehingga menghasilkan pengetahuan tersebut sangat dipengaruhi oleh intensitas perhatian dan persepsi terhadap objek. Sebagian besar pengetahuan seseorang diperoleh melalui indra pendengaran (telinga), dan indra penglihatan (mata) (Notoatmodjo, 2007). Faktor-Faktor yang Mempengaruhi Pengetahuan adalah : faktor internal seperti umur, pendidikan, pekerjaan, sumber informasi dan faktor eksternal seperti lingkungan, sosial budaya (Wawan and Dewi, 2010).

Sikap merupakan reaksi atau respon seseorang yang masih tertutup terhadap suatu stimulus atau objek. Manifestasi sikap itu tidak dapat langsung dilihat, tetapi hanya dapat ditafsirkan terlebih dahulu dari perlilaku yang tertutup. Sikap secara nyata menunjukkan konotasi adanya kesesuaian reaksi yang bersifat emosional terhadap stimulus sosial (Notoatmodjo, 2007).

Rendahnya tingkat keamanan Pangan Jajanan Anak Sekolah (PJAS) masih menjadi permasalahan penting. Data pengawasan PJAS yang dilakukan Badan POM RI Direktorat inpeksi dan sertifikasi Pangan menunjukkan bahwa 45\% PJAS tidak memenuhi syarat karna mengandung bahan kimia seperti formalin, boraks, rhodamin mengandung Bahan Tambahan Pangan (BTP), seperti siklamat dan benzoat melebihi batas aman, serta akibat cemaran mikrobiologi (Pangan and Berbahaya, 2015). Konsumsi jajanan diperkirakan akan terus meningkat, mengingat makin terbatasnya angggota keluarga untuk mengolah makanan. Keunggulan jajanan adalah murah, mudah didapat serta cita rasanya enak. Selain itu, aspek positif dari jajanan adalah dapat menyumbang asupan energi bagi anak usia sekolah sampai protein 29\% dan zat besi 52\%, namun jajanan memiliki aspek negatif terhadap kesehatan akibat dari penggunaan bahan tambahan terlarang dan berbahaya (Rahmanita, 2011).

Pangan jajanan didefinisikan oleh WHO sebagai makanan dan minuman yang dipersiapkan dan/atau dijual oleh pedagang kaki lima di jalanan dan tempat-tempat keramaian umum lain yang langsung dimakan atau dikonsumsi kemudian tanpa pengolahan atau persiapan lebih lanjut. Perlu adanya keamanan pangan yang melekat pada setiap makanan yang akan dikonsumsi masyarakat. Keamanan pangan adalah suatu kondisi dan upaya yang diperlukan untuk mencegah pangan dari kemungkinan cemaran biologis, kimia, dan benda lain yang dapat mengganggu, merugikan, dan membahayakan kesehatan manusia serta tidak bertentangan dengan agama, keyakinan dan budaya masyarakat sehingga aman untuk dikonsumsi. Bahaya konsumsi pangan yang tercemar berasal dari biologis, kimia, maupun benda lain. Cemaran mikroba dan kimia dalam pangan telah diatur dalam Peraturan Kepala Badan Pengawas Obat dan 
Makanan (BPOM) RI. Jenis dan batas maksimum cemaran mikroba dalam makanan diatur berdasarkan kategori pangan sedangkan jenis dan batas maksimum zat kimia meliputi cemaran logam berat dan mikotoksin.

Pendidikan kepada anak sekolah merupakan cara yang sangat efektif untuk mencegah keracunan makanan (foodborne illnes), karena anak tidak hanya belajar tentang keamanan makanan mereka sendiri tetapi juga menyampaikan kebutuhan mereka akan higiene makanan kepada orang tuanya dan anggota keluarga lainnnya. Semakin dini pendidikan tentang keamanan makanan itu dimulai, semakin baik hasilnya. Bahkan anak sekolah taman kanak-kanak pun dapat dilatih tentang beberapa aturan dasar higiene makanan (Adams and Motarjemi, 2004).

Penggunaan Bahan Tambahan Pangan dalam proses produksi pangan perlu diwaspadai bersama, baik oleh produsen maupun oleh konsumen. Dampak penggunaanya dapat berakibat positif maupun negatif bagi masyarakat. Penyimpangan dalam penggunaannya akan membahayakan kita bersama, khususnya generasi muda sebagai penerus pembangunan bangsa. Contoh penggunaan formalin sebagai pengawet makanan akan membahayakan kesehatan selain itu ada juga boraks yang sering ditambahkan pada makanan mie basah, bakso dan lontong. Mie basah yang mengandung boraks memiliki tekstur yang kenyal, lebih mengkilat, tidak lengket dan tidak mudah putus. Bakso yang mengandung boraks teksturnya sangat kenyal, warna tidak kecoklatan seperti penggunaan daging tetapi cendrung lebih keputihan. Apabila dilempar ke lantai akan memantul dan baunya tidak alami. Lontong yang ditambahkan boraks bertekstur sangat kenyal, rasanya tajam seperti sangat gurih dan membuat lidah bergetar serta menimbulkan rasa getir (Alsuhendra, 2013). Dampak boraks bagi kesehatan menyebabkan iritasi saluran cerna yang ditandai dengan sakit kepala, pusing, muntah, mual, diare, penyakit kulit, gangguan otak , hati dan ginjal diikuti terkelupasnya kulit ari.

Penggunaan pewarna berbahaya seperti rhodamin-B adalah salah satu zat pewarna sintetis, yang biasa digunakan pada industri tekstil dan kertas, sebagai pewarna kain, kosmetik, produk pembersih mulut, dan sabun. Nama lain Rhodamin-B adalah D and C Red no 19, Food Red 15, ADC Rhodamine B, Aizen Rhodamine, dan Brilliant Pink. Makanan yang mengandung rhodamin-B mempunyai ciri-ciri: warnanya cerah mengkilat dan lebih mencolok, warna tidak pudar akibat pemanasan (akibat digoreng atau direbus), kadang-kadang warnanya tidak merata, bila dikonsumsi rasanya agak pahit (terutama pada sirup atau limun), muncul rasa gatal di tenggorokan setelah mengkonsumsiya, baunya tidak alami sesuai makanannya, biasanya peroduk makanan yang mengandung rhodamin-B tidak mencantumkan kode, label, merek, atau identitas lainnya. Bahaya utama rhodamin-B dalam jangka waktu yang lama menyebabkan gangguan fungsi hati. Jika terhirup dapat menimbulkan iritasi pada saluran pernafasan. Jika terkena kulit dapat menimbulkan iritasi pada kulit. Jika tertelan dapat menimbulkan iritasi pada saluran pencernaan dan menimbulkan gejala keracunan dan air seni berwarna merah atau merah muda.

Rhodamin-B dalam jangka panjang dapat terakumulasi di dalam tubuh dan dapat menyebabkan gejala pembesaran hati dan ginjal, gangguan fungsi hati, kerusakan hati, gangguan fisiologis tubuh, atau bahkan bisa menyebabkan timbulnya kanker hati.

\section{METODE PELAKSANAAN}

Langkah-Langkah Kegiatan

Pengabdian dilakukan pada bulan Juni dan Juli dengan memberikan penyuluhan sebanyak 2 kali pada murid sekolah di mana penyuluhan pertama pada bulan Juni dan penyuluhan kedua pada bulan Juli. Penyuluhan diberikan dengan media visual dan pemberian 
brosur. Tim pengabdian terdiri dari 4 dosen dimana pembagian tugas nya pada kedatangan penyuluhan pertama di sampaikan oleh 2 dosen dan 2 dosen selanjutnya memberikan penyuluhan pada kedatangan kedua. Pengabdian ini menggunakan randomized pre-test post test control group design, dimana sebelum diadakan penyuluhan yang pertama murid sekolah diberikan pre test kuisioner untuk menilai pengetahuan mereka tentang keamanan PJAS. Kuesioner tersebut diisi langsung oleh masing-masing murid sekolah dan dipandu oleh moderator penyuluhan. Post test kuisioner diberikan pada bulan berikutnya setelah pemberian penyuluhan yang kedua.

Teknik Penyelesaian Masalah

Perilaku jajan sehat sangat diperlukan untuk mecapai keamanan PJAS. Dalam usaha menimbulkan kesadaran murid untuk berprilaku jajanan sehat adalah salah satunya memberikan pengetahuan tentang Pangan Jajanan Yang memiliki ciri-ciri aman untuk dikonsumsi. Sehingga pada pengabdian ini akan diberikan penyuluhan dengan pemberian materi tentang jajanan yang aman dan sehat, materi disampaikan dengan menggunakan media visual dan audio, murid juga diberikan brosur sehingga dapat lebih rinci menerima informasi.

Alat Ukur Ketercapaian

Alat ukur yang digunakan dalam pengabdian ini adalah kuisioner yang terdiri atas 2 bagian yaitu pertanyaan yang memuat pengetahuan dan pertanyaan yang memuat sikap. Skor hasil kuisioner pre test dan post test nantinya dibandingkan sehingga dapat diketahui perubahan tingkat pengetahuan murid siswa sekolah tersebut. Analisis data dilakukan dengan membandingkan nilai/mean 2 kelompok.

\section{HASIL DAN PEMBAHASAN}

Hasil yang didapat adalah adanya peningkatan pengetahuan murid SMA terhadap keamanan PJAS dilihat dari rata-rata skor yang didapat sebelum dan sesudah pemberian penyuluhan sebanyak 2x. Pada kuisioner terdapat 20 buah pertanyaan tentang pengetahuan PJAS dan 15 pernyataan tentang sikap. Hasil pada perlakuan pertama (pre test) pertanyaan tentang pengetahuan didapat rata-rata jawaban yang benar adalah 11 soal dan hasil pada perlakuan kedua (post test) didapat rata-rata jawaban yang benar adalah 19 soal. Sedangkan pada pernyataan tentang sikap responden akan memilih untuk menjawab setuju (S) dan tidak setuju (TS), pada pre test masih terdapat responden menjawab TS pada pernyataan yang seharusnya dijawab $\mathrm{S}$, pada pertanyaan no $3,4,7,10,12,13,14,15$ sebanyak $34,5 \%$ dan pada post test sebanyak $0 \%$ berarti tidak ditemukan lagi sikap yang tidak mendukung keamanan PJAS. 


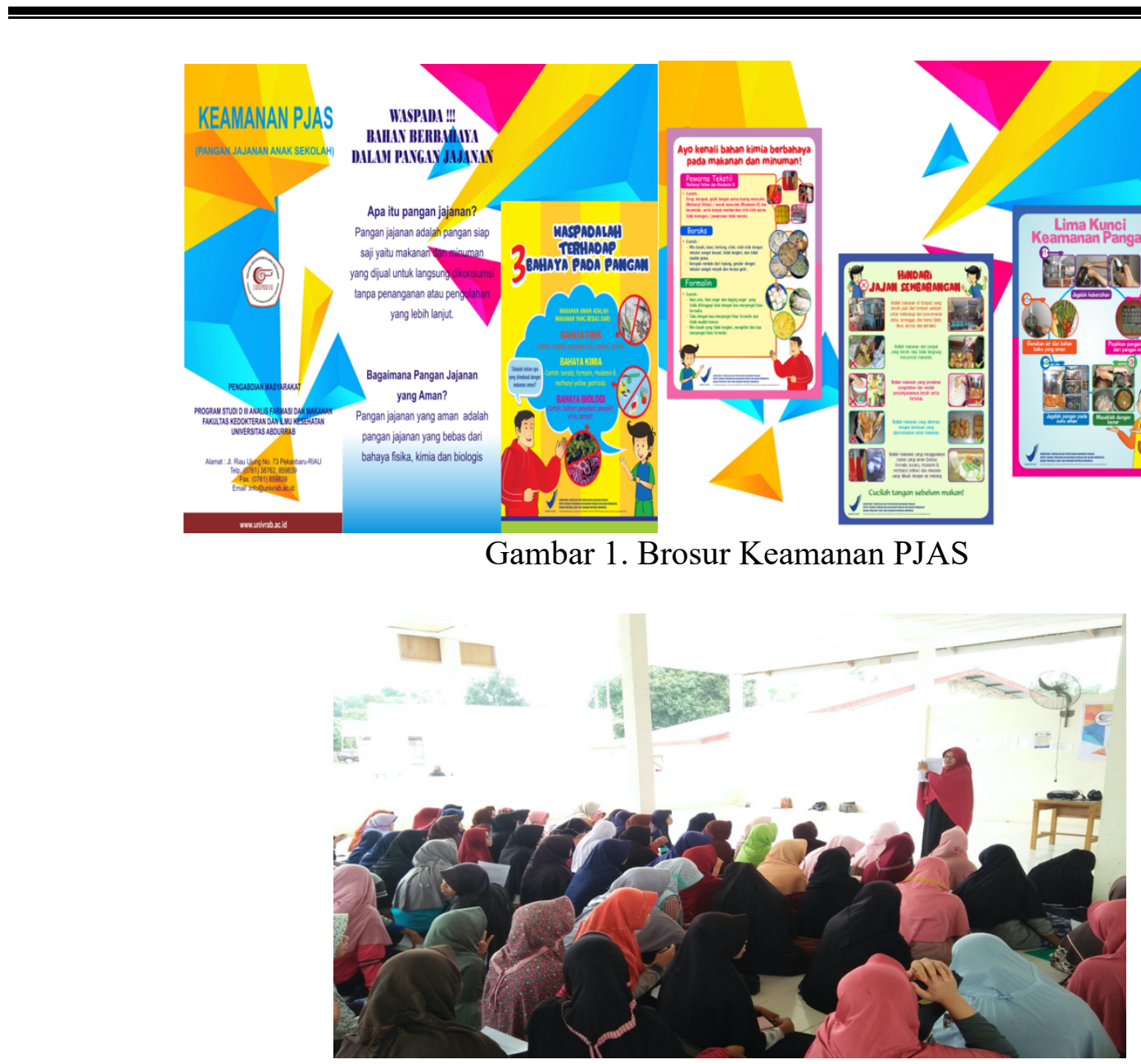

Gambar 2. Responden sedang mendengarkan penyuluhan untuk mendapatkan pengetahuan tentang keamanan PJAS

Pengetahuan terjadi setelah orang melakukan penginderaan terhadap suatu objek tertentu. Penginderaan terjadi melalui panca indera manusia, yakni indera penglihatan, pendengaran, penciuman, rasa, dan raba. Perubahan pengetahuan pada seseorang bisa terjadi akibat pemberian pendidikan/penyuluhan kesehatan, karena pendidikan kesehatan adalah pengalaman belajar yang bertujuan untuk mempengaruhi pengetahuan, sikap dan perilaku yang ada hubungannya dengan kesehatan perseorangan ataupun kelompok (Machfoedz, 2007 ; Notoatmodjo, 2007). Selain pemberian penyuluhan menggunakan media audio dan visual, responden juga diberikan brosur (gambar 1) sebagai bahan bacaan tambahan untuk meningkatkan pengetahuan responden tentang keamanan PJAS. Pemberian brosur ini dinilai sangat efektif karena hasil post test menunjukkan peningkatan pengetahuan.

Sikap merupakan reaksi atau respons yang masih tertutup dari seseorang terhadap suatu stimulus atau objek. Dalam teori S-O-R apabila stimulus telah mendapat perhatian dari organisme (diterima) maka ia mengerti dan setelah itu organisme mengolah stimulus tersebut sehingga terjadi kesediaan untuk bertindak untuk stimulus yang telah diterimanya (bersikap) 
(Suliha, 2001). Hasil pada pertanyaan tentang sikap terdapat peningkatan dari pre test dan post test, hal ini sesuai dengan teori yang dikemukakan.

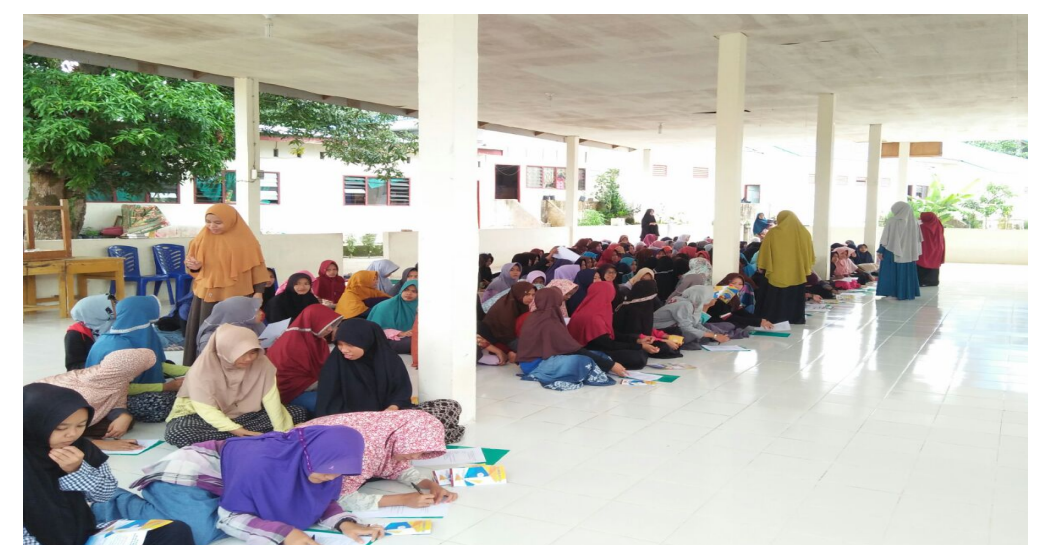

Gambar 3. Responden mengisi kuisioner

Instrumen penelitian adalah alat-alat yang digunakan dalam pengumpulan data (Notoatmodjo, 2007). Pemberian kuisioner dianggap dapat menjadi alat ukur dalam menilai pengetahuan responden, dengan memberikan pertanyaan dan jawaban multiple choice.

\section{KESIMPULAN}

Pemberian penyuluhan dengan menggunakan berbagai macam media dapat meningkatkan pengetahuan dan juga sikap dari responden. Sedangkan untuk perubahan perilaku perlu dilakukan intervensi lebih dalam membutuhkan faktor yang mendukung atau suatu kondisi yang memungkinkan.

\section{DAFTAR PUSTAKA}

[5]. Adams, M. and Motarjemi, Y. 2004. Dasar-dasar keamanan makanan untuk petugas kesehatan, Jakarta: EGC.

[6]. Aini, N. 2017. Mengubah Perilaku Jajan Sembarangan Pada Siswa Sekolah Dasar Melalui Penyuluhan Kesehatan (Changing the Behaviour Street Food Consumption for School Children at Elementary School Klurak Candi Sidoarjo by Health Education). Journal Nursing Care and Biomolecular, 1(1), p. pp-28.

[7]. Alsuhendra, R. 2013. Bahan Toksik dalam Makanan. Bandung: PT. Remaja Rosdakarya.

[8]. Andarwulan, N., Kusnandar, F. and Herawati, D. (2014) 'Analisis pangan'. Universitas Terbuka.

[9]. Cahyadi, W. 2008. Analisis \& Aspek Kesehatan Bahan Tambahan Pangan. ed. II. Jakarta: Sinar Grafika Offset, pp. 5-12.

[10]. Eka, R. 2013. Rahasia Mengetahui Makanan Berbahaya. SPASI MEDIA.

[11]. Notoatmodjo, S. 2007. Promosi Kesehatan dan Ilmu Perilaku. Jakarta: Rineka Cipta.

[12]. Pangan, D. P. T. and Berbahaya, B. 2015. Laporan Kinerja Tahun 2014, Direktorat Perlindungan Tanaman Pangan, Ditjen Tanaman Pangan Kementerian Pertanian, Jakarta.

[13]. Rahmanita, I. 2011. Hubungan Pengetahuan, Sikap serta Perilaku Ibu mengenai Jajanan 
Anak SD Yang Mengandung Bahan Pengawet dan Pewarna di Kelurahan Beringin Jambi Tahun 2011, Program Studi Pendididkan Dokter Fakultas Kedokteran Dan Ilmu Kesehatan UIN Syarif Hidayatullah Jakarta. Jakarta.

[14]. RI, D. P. O. M. D. 1995. Farmakope Indonesia, ed. IV, Departemen Kesehatan RI, Jakarta.

[15]. Thah, H. M. and Yuwono, S. S. 2014. Analisis Preferensi, Perilaku Mahasiswa Dan Keamanan Pangan Terhadap Produk Bakso di Sekitar Universitas Brawijaya', Jurnal Pangan dan Agroindustri, 2(4), pp. 89-100.

[16]. Wawan, A. and Dewi, M. 2010. Teori dan Pengukuran Pengetahuan, Sikap dan Perilaku Manusia. Yogyakarta: Nuha Medika, pp. 15-20.

[17]. Yuliarti, N. 2007. Awas Bahaya di Balik Lezatnya Makanan, Yogyakarta : Andi Ofset 